Zoologica Poloniae (2008) 53/1-4: 49-56

$10.2478 / \mathrm{v} 10049-008-0005-4$

\title{
VARIATION OF THE COMMON SHREW (SOREX ARANEUS L.) DENTITION
}

\author{
Magdalena Moska, MaŁgorzta Laskowska, Barbara \\ Kosowska, Tomasz StrzaŁA and Bożena MARszaŁeK-KruK
}

Department of Genetics and Animal Breeding, University of Environmental

Sciences, Wrocław, Poland: E-mail: magdalena.moska@up.wroc.pl

\begin{abstract}
Variation of the upper arch dentition was studied in 162 individuals of Sorex araneus. Seven types of dentition were observed. Type V dentition was the most common (constituting $54.2 \%$ of the analysed dental rows), while type $\mathrm{VII}_{2}$ was the rarest $(1.4 \%)$. Dental anomalies, i.e. retention or polyodontia, were not found in the analysed material.
\end{abstract}

Key words: dentition variation, Sorex araneus, dentition types, unicuspid teeth

\section{INTRODUCTION}

The common shrew (Sorex araneus Linneus, 1758), a representative of the order Insectivora, is a non-specialized predator, feeding on the most easily available food. It feeds mostly on insects and other small invertebrates, and also, although much less frequently, on small vertebrates. Moreover, it is not averse to plant food (PUCEK, 1984). The species is characterized by an extremely high metabolism rate, what necessitaes a constant food supply (TYLOR, 1998).

The dentition of $S$. araneus, like that of all other shrews (Soricidae), is highly specialized. At least two different dental formulas describing its dentition have been presented in the literature. According to PUсек (1984), the upper dental row contains 3 pairs of incisors, one pair of canines and 3 pairs of premolars and molars each. The lower dental row contains 2 pairs of incisors, 1 pair of premolars and 3 pairs of molars (Fig. 1a). A slightly different pattern of dentition has been proposed by DANNELID $(1989,1998)$, who distinguished in the upper dental row a pair of incisors $\left(\mathrm{I}^{1}\right)$, followed by five pairs of unicuspid 


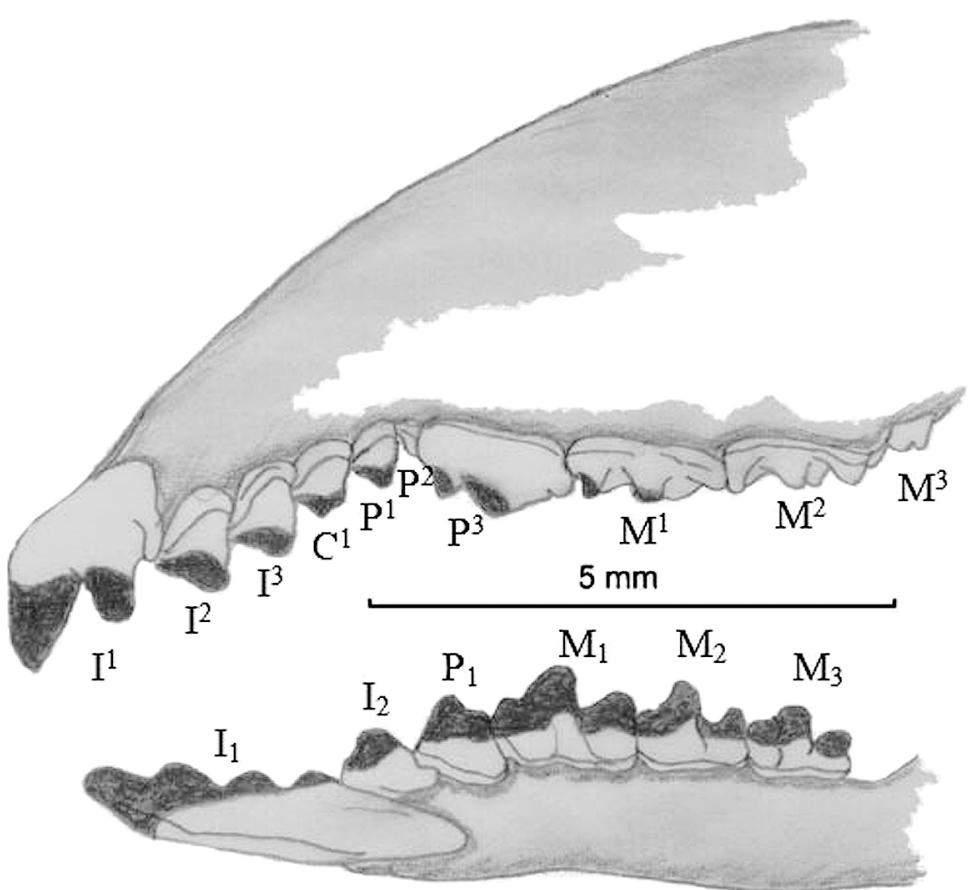

a)

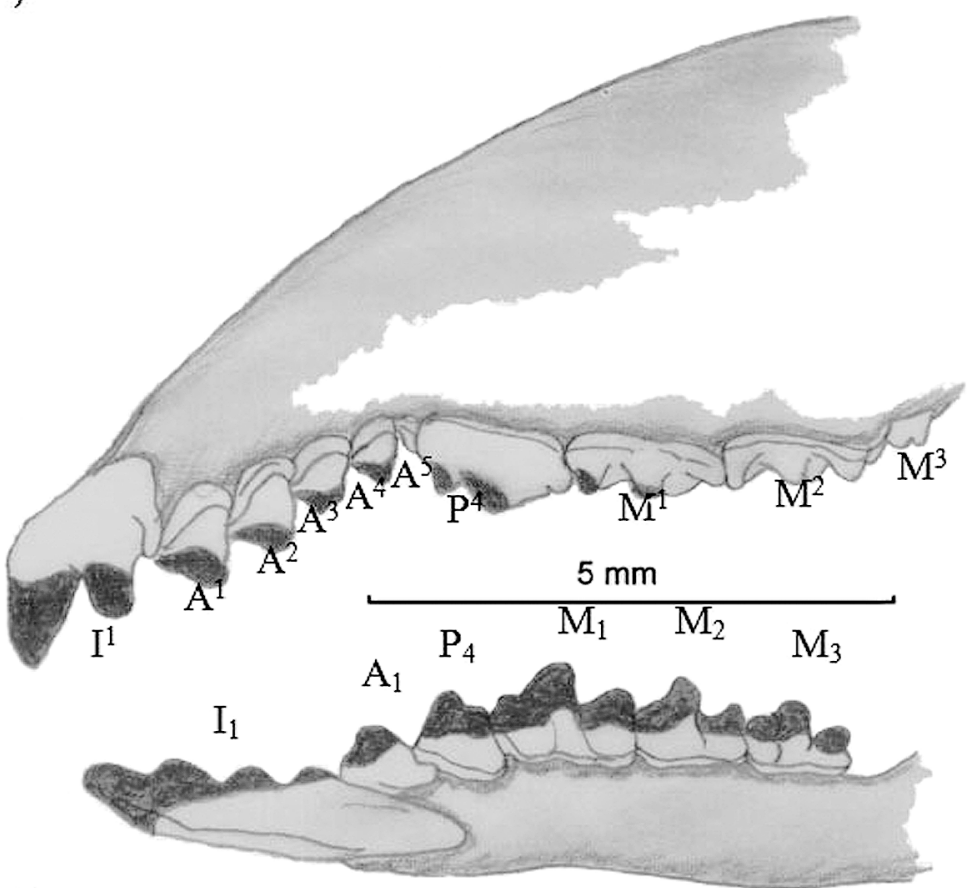

Fig. 1. Dental formula of Sorex araneus. a - according to PUcEK (1984), b - according to DANNELID (1989) 
or anterior cheek teeth (antemolars $\mathrm{A}^{1}, \mathrm{~A}^{2}, \mathrm{~A}^{3}, \mathrm{~A}^{4}, \mathrm{~A}^{5}$ ), a pair of premolars and 3 pairs of molars $\left(\mathrm{M}^{1}, \mathrm{M}^{2}, \mathrm{M}^{3}\right)$. In the mandible Dannelid (1989) distinguished a pair of incisors $\left(\mathrm{I}_{1}\right)$, followed by one pair of each, anterior cheek $\left(\mathrm{A}_{1}\right)$ and premolar teeth $\left(\mathrm{P}_{4}\right)$ as well as three pairs of molar teeth $\left(\mathrm{M}_{1}, \mathrm{M}_{2}, \mathrm{M}_{3}\right)$ (Fig. 1b).

\section{Dentition types in S. araneus}

$S$. araneus displays a wide individual variation of the unicuspid teeth in the upper dental arch (Tab. 1). A gradual decrease in the size of the teeth, starting from the first incisors to the last teeth, with the first tooth being slightly larger or equal to the second, third markedly smaller than the second, fourth - significantly smaller than the third and the fifth- very small, was initially thought to be a constant character of the species (Miller,1912; OGNIEv, 1928).

However, Stroganov (1936), and next Dehnel (1949), Kubik (1951) and SeRAfiŃSKi (1955) noticed that the incisors pattern proposed by Miller (1912) and OGNiev (1928) was not fixed. They distinguished 3 types of dentition in $S$. araneus: 1) equal (backward decrease of the size of the teeth), 2) paired, the so-called 2:2 (two first teeth of the same size, two second teeth also of the same size, but smaller than the previous ones, fifth tooth very small), 3) intermediate, also referred to as mixed type (combining the features of both types presented above). Moreover, KubiK (1951) and Serafiński (1955) found that the teeth pattern could differ on the right and left side of the upper dental arch in the same individual. These animals were referred to as "mixed".

An even more detailed classification of $S$. araneus dentition was proposed by Dolgov (1968a), who distinguished eight types (Tab. 1): type I - unicuspid teeth constituting two distinct groups, first tooth equal to the second one, third equal to the fourth, but smaller than the second, fifth - very small, type II - first tooth equal to the second, third tooth smaller than the previous ones, fourth - smaller than the third, fifth - very small, type III - first tooth - the largest, second - smaller than the first, third - smaller than the second and equal to the fourth, fifth - very small, type IV - unicuspid teeth constitute two distinct pairs, in which the second tooth of a pair is smaller than the first one, and the first pair is bigger than the second; fifth tooth - very small, type $\mathbf{V}$ - the size of unicuspid teeth decreases gradually from the first tooth to the fifth one, corresponding to the equal type, type VI - first unicuspid tooth is the largest, second - smaller that the first one and equal to the third tooth, fourth - smaller than the third, fifth - very small, type VII, including two subtypes - first tooth smaller than the second, VII ${ }_{1}$ third and fourth teeth smaller than the first and second and equal to each other, $\mathbf{V I I}_{2}$ third tooth significantly larger than the fourth, fifth - very small.

\section{S. araneus dentition anomalies}

The anomalies in S. araneus dentition first of all concern the number of unicuspid teeth. They consist in sporadic unilateral or bilateral retention of the fifth unicuspid tooth (Pucek, 1984). Dolgov (1968b) describes cases of retention 
of the upper fifth tooth on the left or on the right side and a simultaneous lack of teeth on both sides. When the fifth tooth was missing, the remaining teeth were normal size and they were distributed freely in the dental arch.

Apart from teeth retention, supernumerary teeth have been described in $S$. araneus. The anomalies included the presence of a supernumerary unicuspid tooth on the left side of the upper dental arch, between the third and fourth teeth. The tooth was significantly smaller than teeth four and five; its anterior surface adhered closely to the posterior surface of the third tooth, the size of which was unchanged. The fourth tooth was shifted outside the arch and slightly smaller than its counterpart on the right side (Dolgov, 1968b).

The aim of the study was to analyse the intra-specific variation of antemolars and dentition anomalies in $S$. araneus.

\section{MATERIAL AND METHODS}

The material included 162 skulls of S. araneus obtained in 1996-1999. A total of 317 upper dental rows (right and left) were analysed. The animals came from north-east Poland (268 dental arches) and south-west Poland (49 dental arches). The material included only the skulls of young animals, i.e. born in the year they were trapped. This fact guaranteed good condition of the analysed dentition, which minimised possible errors in the evaluation of the dentition type.

The analysis of dentition was performed with the use of stereomicroscopea; the teeth were viewed with a 4 -fold magnification. In every animal the dentition types were analysed in the upper dental arch on the left and on the right side. Moreover, the number of unicuspid teeth was analysed to diagnose possible retention or polydontia.

\section{RESULTS}

Seven types of dentition were found in the analysed material. In all types the fifth antemolar $\left(\mathrm{A}^{5}\right)$ was the smallest.

1. Type I - first two unicuspid teeth of the same size, next two teeth also of the same size, but smaller than the first teeth;

2. Type II - first two teeth equal, third tooth smaller than the second, fourth - smaller than the third, fifth - very small;

3. Type III- first unicuspid tooth wider, second - smaller than the first one, third- smaller than the second and equal to the fourth, fifth tooth - very small;

4. Type IV - first unicuspid tooth minimally larger than the second tooth, third tooth minimally larger than the fourth tooth, fifth tooth - very small. Distinct division into two groups of teeth;

5. Type $\mathrm{V}$ - unicuspid teeth decrease in size from the first to the fifth tooth; 
6. Type VII - first unicuspid tooth smaller than the second; third and fourth teeth equal and smaller than the first one, fifth tooth - very small;

7. Type $\mathrm{VII}_{2}$ - first unicuspid tooth smaller than the second, third - smaller than the first, but bigger than the fourth tooth, fifth tooth - very small.

The analysis revealed that the most common dentition type observed in the analysed material was type $\mathrm{V}$, which was found in $54.2 \%$ of dental arches. It was followed by type II (23.0\%), and then by types: IV (15.1\%), I (3.1\%), VII and III (1.6\%) as well as VII $(1.4 \%)$ (Tab. 2). At the same time type VI dentition according to Dolgov (1968a) was absent in the whole material.

Tab. 1. Different types of dentition of Sorex araneus proposed by different authors

\begin{tabular}{cccl}
\hline Lp. & \multicolumn{2}{c}{ Type of dentition } & \multicolumn{1}{c}{ Source } \\
\hline 1. & $1>2>3>4>5$ & & MILLER, 1912; OGNIEV, 1928 \\
2. & $1>2>3>4>5$ & equal & \\
3. & $(1=2)>(3=4)>5$ & paired $(2: 2)$ & STROGANOV, 1936; DEHNEL, \\
4. & combining the features of & intermediate & $1949 ;$ KUBIK, 1951; SERAFIŃSKI, \\
& types equel and paired & & 1955 \\
5. & $(1=2)>(3=4)>5$ & typ I & \\
6. & $(1=2)>3>4>5$ & typ II & \\
7. & $1>2>3=4>5$ & typ III & \\
8. & $(1>2)>(3>4)>5$ & typ IV & DoLGOV, 1968 \\
9. & $1>2>3>4>5$ & typ V & \\
10. & $1>2=3>4>5$ & typ VI & \\
11. & $(1<2)>(3=4)>5$ & typ VII & \\
12. & $1<23>4>5$ & typ VII 2 & \\
\hline
\end{tabular}

Tab. 2. Number of dental arches represents different types of dentition (n) and percentage share of types of dentition in all material

\begin{tabular}{cccccccc}
\hline Dentition type & I & II & III & IV & V & VII $_{\mathbf{1}}$ & VII $_{\mathbf{2}}$ \\
\hline $\mathrm{n}=317$ & 10 & 73 & 5 & 48 & 172 & 5 & 4 \\
$\%$ of all arches & 3.1 & 23.0 & 1.6 & 15.1 & 54.2 & 1.6 & 1.4 \\
\hline
\end{tabular}

Shrews with two different dentition types on the left and on the right side constituted $42.3 \%$ of all the investigated animals. The analysis of unicuspid teeth for retention or polydontia did not reveal any of these anomalies in the investigated material. 


\section{DISCUSSION}

Several types of dentition were described in the common shrew, but a consistent classification is missing. The dentition type in which unicuspid teeth decrease gradually in their size backwards, accepted as a species character by Miller (1912) and Ogniev (1928), was recognized as one of three types on the basis of subsequent studies by Stroganov (1936), Dehnel (1949), KubiK (1951) and Serafiński (1955). Four different types of dentition were proposed by JUdin (1989), and as many as 8 types - by Dolgov (1968a). The above facts illustrate the wide variation of $S$. araneus dentition.

The aim of the present study was to analyse the upper dental arch dentition in shrews of Poland. Considering the individual dentition types in the investigated material, type $\mathrm{V}$ corresponds to the equal type, type $\mathrm{I}$ - to the paired type (2:2), and types II, III, IV, VII ${ }_{1}$ and $\mathrm{VII}_{2}$ are the intermediate types according to Stroganov (1936), Dehnel (1949), Kubik (1951) and Serafinśri (1955).

The analysis showed that type V (i.e. equal), which was found in over half of the dental arches, predominates among shrews. The second most common type was type II, and the third - type IV (both represent the intermediate type). Using 3-group classification (equal, paired and intermediate types) it appears that type I (paired) occurs relatively rarely (it was found in $3.1 \%$ of upper dental arches). Thus the findings are similar to the data of Serafinssi (1955), who found in his material that the majority of animals had the equal type of dentition, animals with intermediate dentition were the second most common group, and the paired type was the least frequent. However, they differ from DeHnel's (1949) and KUBIK's (1951) results, where the majority of animals had the intermediate type of dentition. Still another dentition type - type I (paired) predominated in Dolgov's (1968a) material, including 734 animals from 9 populations from different parts of the former Soviet Union. This dentition type was found in $45.6 \%$ of animals, followed by types II and IV (14.5\%) and III (12.9\%). The least common dentition type listed by Dolgov was type VI. In this type of dentition, the first unicuspid tooth is the biggest, the second is smaller than the first and equal to the third, the fourth is smaller than the third and the fifth is very small. This dentition type was found only in 11 (out of over 700) animals, which constitutes $1.5 \%$. All the animals which revealed this type of dentition came from one population inhabiting West Sajan in South Siberia. The percentage of animals with this type of dentition in the population was also low $14.5 \%$. The extremely low frequency of occurrence of type VI and its range limited to South Siberia probably explains the lack of this dentition type in the studied material.

Moreover, the study also investigated the proportion of the so-called "mixed" animals, i.e. those in which the right and left dental rows represent different types of dentition. The analysis showed that it was a surprisingly common phenomenon - as much as $42.3 \%$ animals revealed different type of dentition on the right and left sides of the upper dental arch. According to 
KubiK (1951) and SerafińsKi (1955), they also had such animals in their material, however due to the lack of numerical data, their percentage in the whole material cannot be compared.

None of the 162 animals analysed in the present study revealed anomalies in the number of teeth, neither unicuspid, nor premolars or molars. Dental anomalies in the form of retention and polydontia are rarely observed in the shrew and they mostly involve the unicuspid teeth. This is confirmed by the data of Feldhammer and Stober (1993), who investigated 576 north-American shrews and found only 29 cases $(0.5 \%)$ of dental anomalies. Unicuspid teeth retention was also observed by JUDIN (1989). Having analysed the dentition in about one thousand animals he observed unilateral or bilateral oligodontia of only one unicuspid tooth. Most commonly it affected the third, fourth and fifth tooth.

Anomalies in the number of molar and premolar teeth are even less common. Only one such case has been reported in the shrew family - in Crocidura (SeTZER, 1957). On this basis some authors suggest that these teeth are more important for survival of the animal than the unicuspid teeth (Feldhammer and StOBER, 1993).

\section{ZRÓŻNICOWANIE UZĘBIENIA RYJÓWKI AKSAMITNEJ (SOREX ARANEUS L.)}

Zbadano zróżnicowanie uzębienia górnego łuku zębowego 162 osobników S. araneus. W badanym materiale stwierdzono występowanie 7 różnych typów uzębienia. Najczęściej występującym typem był typ V (stanowiący 54,2\% przeanalizowanych szeregów zębowych), a najrzadziej typ VII (odpowiednio 1,4\%). Nie stwierdzono występowania typu VI. Brak w badanym materiale anomalii uzębienia tj. retencji lub polidoncji.

\section{REFERENCES}

Dannelid, E., 1989: Medial tines on the upper incisors and other dental features used as identification characters in European shrews of the genus Sorex (Mammalia, Soricidae). Zeitschrift für Säugetierkunde, 54: 205-214.

Dannelid, E., 1998: Dental adaptations in Shrews. Pp. 158-173. In WóJcik, J.M. and Wolsan M (eds): Evolution of shrews. Mammal Research Institute. Polish Academy of Sciences.

Dennel, A., 1949: Studies on the genus Sorex L. Annales Universitatis Mariae CurieSkłodowska, Lublin, 4: 17-97.

Dolgov, B., 1968a: Osobiennosti i izmiencziwost odontologiczeskich priznakov palearkticzeskich burozubok (Mammalia, Sorex). Sbornik Trudov Zoologiczeskawa Muzjeja MGU, 10: 179-190. [In Russian]

Dolgov, B., 1968b: Anomali zubnoj sistiemy burozubok (Mammalia, Sorex). Sbornik Trudov Zoologiczeskawa Muzjeja MGU, 10: 222-224. [In Russian]

Feldhammer, G.A. \& Stober, T.L., 1993: Dental anomalies in five species of North American shrews. Mammalia, 57: 115-121. 
Judin, A., 1989: Nasekomojadnyje mlekopitajuszcie Sibiri, Nowosybirsk, 282-307. [In Russian]

Kubik, J., 1951: Analysis of the Puławy population of Sorex araneus araneus L. and Sorex minutus minutus L. Annales Universitatis Mariae Curie-Skłodowska, Lublin, 5: 335-372. [In Polish]

Miller, G.S., 1912: Catalogue of the Mammals of Western Europe. London.

Ogniev, S.I., 1928: Zwieri Wostocznoj Ewropy i Sewernoj Azji. Moskwa. 2: 19311954. [In Russian]

Pucek, Z., 1984: Common shrew (Sorex araneus). Pp. 60-85. In Pucek et al. (eds): Keys to Mammals of Poland PWN, Warsaw. [In Polish]

Serafiński, W., 1955: Morphological and ecological studies of Polish species of Sorex L. (Insectivora, Soricidae). Acta Theriologica, 1: 27-81. [In Polish]

Setzer, H.W., 1957: An extra tooth in Crocidura. Journal of Mammalogy, 38: 258-259.

Stroganov, S.U., 1936: Fauna mlekopitajuszczich Wałdajskoj wozwyszennosti. Zoologiceskij Zhurnal, 15: 128-559. (In Russian)

TAYLOR, J.R.E., 1998: Evolution of energetic strategies in shrews. Pp.309-346. In: Wójcik, J.M. \& Wolsan, M. (eds): Evolution of shrews Mammal Research Institute Polish Academy of Sciences, Białowieża. 